\title{
SGLD 行列を用いたカラー自然背景からの低画質顔画像の抽出
}

\author{
学生員 戴䝁 (信州大学) 正員 中野康明 (信州大学)
}

\author{
Extraction of Facial Images from the Complex Background Using Color \\ Information and SGLD Matrices \\ Ying Dai, Student Member and Yasuaki Nakano, Member (Shinshu University)
}

\begin{abstract}
It is the key step for face recognition systems to extract the facial parts from the complex backgrounds. In this paper, we propose a new method for the face extraction in the color complex backgrounds. By transforming color images from RGB color represention to YIQ color one, the orange-like parts including the face areas are enhanced in the original images, if the I-componet of YIQ color system is only used. The facial texture model based on the space gray level dependence (SGLD) matrices is applied to these images. Using this model, facial parts are detected as those regions which satisfy a set of inequalities. The weight coefficients in the inequalities are decided by the conventional method of learning. Using this textural model, we design a kind of scanning scheme for face detection in the complex backgrounds. The experiments show that this method could locate the face position in the complex backgrounds effectively. キーワード：顔画像検出、共起行列
\end{abstract}

\section{1.まえがき}

出入室管理、身分証明書の確認、犯人の搜査その他で 個人同定に対する要望が高まっており、顔画像識別に関 する研究、実用化の推進が期待されている。

顔画像認識に関する多くの研究では确画像が既に検出 されたと仮定している(1)-(3)。しかしながら、顔画像 認識の前段処理として、複雑背景画面内からの顔の自動 検出が不可久である。さらに、低画質画像からの顔画像 を抽出する方法が必要である。

顔画像抽出の研究は数少い。Yang $5^{(5)}$ 悎層的知 識べースを使った自然画像からの顔抽出法を提案した。 小杉 (4) は多重ピラミッドを用いた顔の抽出手法を提案 した。Govindaraju ${ }^{(6)}$ は顔形状をモデル化し、これを 画像中から探索した。Turk ${ }^{(7)}$ は顔画像の固有ベクトル 展開を用いた抽出法を提案した。これらの方法では複雑 な自然背景から大きさ末知の顔部分が抽出できるが、顔 画像の分解能が十分高いこと、既部分と背景部分のコン トラストが十分大きいことなどの条件が満たされなけれ ばならない。すなわち、高解像度の画像からの顔検出に ある程度有効な手法は開発されているが、これらが、低 解像度画像に適用可能かどうかは明きらかでない。

筆者ら ${ }^{(10)}$ は自然画面の任意の位置にある複数の低 画質正面顔を探し出す”顅探索”を目標として、共起行 列を用い、白黒顔画像のテクスチャ特徴モデルと、それ を用いた顔唡出手法を提案した。この手法は、16 1620
画素程度の空を用いて画像を走查し、モデルに適合す る部分を顔として抽出するものである。本手法を用い た実験結果は高い検出率を示したが、多少の虚報 (false alarm) も含まれるという問題があった。

本論文は上記の問影点に対して、虚報を除去すると ともに、処理速度を向上させるため、カラー情報を利用 する方法を検討した。まず、入力されたカラー画像につ いて、RGB表色系を $\mathrm{YIQ}$ 表色系に变換する。YIQ 表 色系のI信号を利用して、オレンジからシアンまでの色 だけを含んでいる画像を作成し、顔部分を強調した単色 画像を作る。この単色画像に、前論文 ${ }^{(10)}$ の手法を改良 した手法を適用する。

本手法の有効性を確䛇するために、行なった実験の 結果を述べる。

\section{2. 白黒顔画像のテクスチャ特徴モデル}

この節では前論文 (10) で提案した白黒西像からの新 抽出方法を筇単に述べる。

\section{1 共起行列}

Haralick $^{(8)}$ は共起行列を使ったテクスチャ解析の手 法を提案した。この手法を简単に説明する。画像中の任 意点 $(i, j)$ とそれから $(m, n)$ だけ離れた点 $(i+m, j+$ $n)$ をとり、その 2 点の浱度が $a, b$ でったとする。い ま $(a, b)$ を固定し、 $(i, j)$ を全画面にわたって変化させ 
て、浱度 $(a, b)$ の組合せが生じる度数 $N_{a b}(m, n)$ を計数 する。

$N_{\mathrm{ab}}(m, n)$ は、浱度 $(\mathrm{a}, \mathrm{b})$ の組合せが空間的に $(m, n)$ だけ離れた 2 点間に生じる事象であるが、このような事 象の生じる哊率は近似的に

$$
\begin{aligned}
P_{a b}(m, n) & =\operatorname{prob}\{f(i, j)=a, f(i+m, j+n)=b\} \\
& =\frac{N_{a b}(m, n)}{T}
\end{aligned}
$$

と見なせる。ここで、Tは画像の総画素数である。 この共起行列を用いて、2 点の空間的相互関係を表す パラメータとして、次のようなものが考えられる。

$$
\begin{gathered}
B_{I}(m, n)=\sum_{a=0}^{L-1} \sum_{b=0}^{L-1}(a-b)^{2} P_{a b}(m, n) \\
B_{D}(m, n)=\sum_{a=0}^{L-1} \sum_{b=0}^{L-1} \frac{P_{a b}(m, n)}{1+(a-b)^{2}}
\end{gathered}
$$

$$
B_{C}(m, n)=\frac{1}{\sigma^{2}} \sum_{a=0}^{L-1} \sum_{b=0}^{L-1}(a-\mu)(b-\mu) N_{a b}(m, n)
$$

ここで、 $B_{I}(m, n) 、 B_{D}(m, n) 、 B_{C}(m, n)$ はそれそ れ慣性、 inverse difference、共分散特徽パラメータ上 乎价る。 $L$ は浱度の段階数 $(0,1, \ldots, L-1)$ を示す。 $\mu$ と $\sigma$ は画像の瀑度の平均值と標浌偏差である。ある筑 囲で $m 、 n$ を変化させ、 $B_{I}(m, n) 、 B_{D}(m, n)$ 、 $B_{C}(m, n)$ を要素とする行列 $B_{I} 、 B_{D} 、 B_{C}$ を作る。

$$
B_{I}=\left(\begin{array}{ccc}
B_{I}(0,0) & \ldots & B_{I}(M, 0) \\
& & \\
B_{I}(0, N) & \ldots & B_{I}(M, N)
\end{array}\right)
$$

ここで、 $M$ と $N$ は $m$ と $n$ の最大値を表す。 $B_{D} 、 B_{C}$ は上式の添字をそれぞれ $\mathrm{D}, \mathrm{C}$ に変えたものである。

$B_{C}$ は、前論文 $(10)$ では使用しなかったが、カラー画 像の挨討の便宜上、同時に示す。

2.2 共起行列による白黒顔画像テクスチャモデル 顏画像は特別なテクスチャ特街をもつと考えられる。 䫀画像の特徽として、次の点が挙げられる。

1)顔画像は方向性や周期性をもたず、均一性をもつ。

2) 中心軸に対して、ほほ左右対称である。

3)䫫画像の浱度值の分布は、一般的に、目と並行する 方向の変化が目と垂直方向の変化より小さい。こ れは眼やロの存在と㑈の形の影警である。

4)顔の内部では画像の浱淡変化は局所的に一様、すな わち、ごく小さい筑囲で一様と考えられる。

上の考察によって、共起行列 $B_{I}$ や $B_{D}$ を用いた白黒 碩画像のテクスチャ特徴モデルは次のように表される。
ある画秦 $(i, j)$ の近傍画素領域を

$D_{p}=\{(k, l): 0 \leq k-i \leq M$, and $0 \leq l-j \leq N\}$, で表す。ここで、 $m 、 n$ の最大值 $M 、 N$ は顔部分の 画像の解像度に応じて定める。 $D_{p}$ は $(M+1) \times(N+1)$ の行列で表される。前論文 ${ }^{(10)}$ では低品質画像の抽出を 研究の対象として、大きさがほほ $16 \times 20$ 画素の顔画像 を扱ったが、そのとき $M=2$ と $N=2$ で実跧した。

$\mathrm{M}, \mathrm{N}$ の值が 2 のとき、モデルの記法を簡単にするた めに、 $B_{I} 、 B_{D} 、 B_{C}$ の要素を次の行列に示すように 番号付けする。

$$
D=\left(\begin{array}{lll}
1 & 2 & 5 \\
3 & 4 & 7 \\
6 & 8 & 9
\end{array}\right)
$$

ここで、数字はその要素に対応する番号である。

白黒顔画像では $B_{I}$ と $B_{D}$ について多数のサンプルを 視察し、欧式が成立することを見出した ${ }^{(10)}$ 。

$$
B_{I}\left(j_{1}\right)<(1+w) B_{I}\left(j_{2}\right) \quad\left(j_{1}<j_{2}\right)
$$

ここて、 $w$ は正定数で、 $j_{1}, j_{2}$ は $B_{I}$ の要素の番号であ る。同様に $B_{D}$ について、

$$
B_{D}(j)<c \quad(1<j \leq 9)
$$

ここで、 $0<c<1$ は定数である。

この関係を利用して、ある領域のなかで、行列 $B_{I}$ や $B_{D}$ を計算し、これらの行列の要素が不等式 $(7)$ と $(8)$ を満たすとき、その領域は顔領域と判定する。

パラメータ $w$ と $c$ はできるだけ小さな方が非願画像 を排除できるが、一方では、顔画像を見落す危険があ る。高い判別率の下で、できるだけパラメータを小さく するため、赛験サンプルによって、 $w=0.3, c=0.6$ を 最適值にする(10)。

\section{3 実酸結果}

150 個の垂直正面顔を含む白黒複雑自然背景画像 60 枚を使って、颜抽出の実験を行った。これらの害験用の 画像背景は自然界の情景である。顔は画像中の任意の位 置にあり、顔の大きさは $16 \times 20$ から $20 \times 26$ まで変化 していた。実験の結果として、60枚画像中の全部の顔 が正確に抽出され、見落とし率は $0 \%$ であった。しかし ながら、5枚の画像で、一つまたは二つの非顔部分が顔 として抽出された ${ }^{(10)}$ 。

\section{3. カラー信号の利用}

3.1 カラー自然情景画像からの色差信号の分離 日本においては、少数を除き人間の肌色の差は小さ い。この肌色のみをカラー自然背景から分離したら、 顔抽出における妨害要因が減少できる可能性がある。 YIQ 表色系ではIがオレンジからシアンまでの色を含 んでいるので、YIQ 表色系のI信号を利用すれば、肌 色を含んでいるオレンジからシアンまでの色の部分を残 して、他の部分を取り除くことができると考えられる。 
RGB から YIQ への変換式を以下に示す。

$$
\left(\begin{array}{c}
Y \\
I \\
Q
\end{array}\right)=\left(\begin{array}{ccc}
0.299 & 0.587 & 0.114 \\
0.596 & -0.274 & -0.322 \\
0.211 & -0.522 & 0.311
\end{array}\right)\left(\begin{array}{c}
R \\
G \\
B
\end{array}\right)
$$

I 成分の值が 0 のときは無彩色 (扊色) を示す。上記の $\mathrm{RGB}$ から $\mathrm{YTQ}$ への変換式において、 $\mathrm{R}, \mathrm{G}, \mathrm{B}$ 各成 分が 0 〜 255 で表されるとき、I 成分の最大值は約 150 である。I成分画像は白里画面上で、0が黒色で、值が 大きいほど白くなるように表示した。

I 成分の值が 1 から 150 まで変化するとき、色の成分 はオレンジからシアンまで変化している。このうち、 肌色を含むオレンジ色成分は 1 から 50 までの範囲であ る。I の值は大きいほどオレンジの成分が少なく、シア ンの成分が大きくなる。上の観察によって、画像のなか に肌色を含むオレンジ色成分だけ残すためには、I成分 で 1 から 50 までの数值を残せばよいことが分かる。

図 1は顔をもつ原画像と 1 から 50 までの間の I 成分 だけを残し、上下をカットして、值 0 にした画像を示し たものである (原画像はカラーであるが、印刷の都合で 白黒画像で表示した。)。簡単のため、このように振幅 フィルタをかけた I 成分画像を、以後は I 成分画像と呼 ふ。

図1(a) で分かるように、このI 成分画像は、顔の部 分にほほ該当する部分が明るくなっている。目と眉は黒 いので、I 成分画像のなかでも目と眉はそのままの形で 黒く残っている。通常唇に対応するI の值は肌に対応す るIの值より大きいから、唇はI 成分画像で白い色をし ていて、その形は変わらない。ただし、唇に対応するI の値が 50 より大きくなることもあり、その場合はカッ トされてしまう。すなわちI成分画像で黒い色になる。 これらの部分を除けば、I 成分顔画像の婊淡の分布は白 黒顔画像と似ている。

図 1(b) で分かるように、処理後の画像のなかでは顔 を含むオレンジ系の色の部分が高い泿度で強調され、他 の色の部分はほとんど除去される。すなわち、原画像に おけるオレンジ系の色以外の部分は除去され、顔抽出に 具合の良い形となっている。

次節では、このI信号のみを含んでいる画像に基づい た顔部分の抽出方法を検討する。

\section{2 カラー顔画像のテクスチャ特徴モデル}

第 2 章で简単に述べた方法では、自然情景䈨画像 から、共起行列 $B_{I}$ と $B_{D}$ を利用して顔画像を抽出した が、本論文ではカラー自然背景画像の中の顔画像の抽出 手法を検討する。前節の考察により、I 成分画像では顔 部分が強調され、白黒顔画像とだいたい同じ婊淡分布傾 向をもつことが分かる。

I 成分画像について共起行列を求めると、顔画像の共 起行列によるテクスチャモデルは次のように表される。

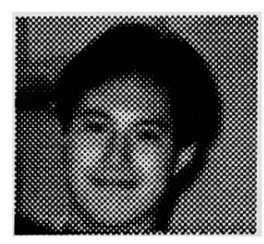

(a)
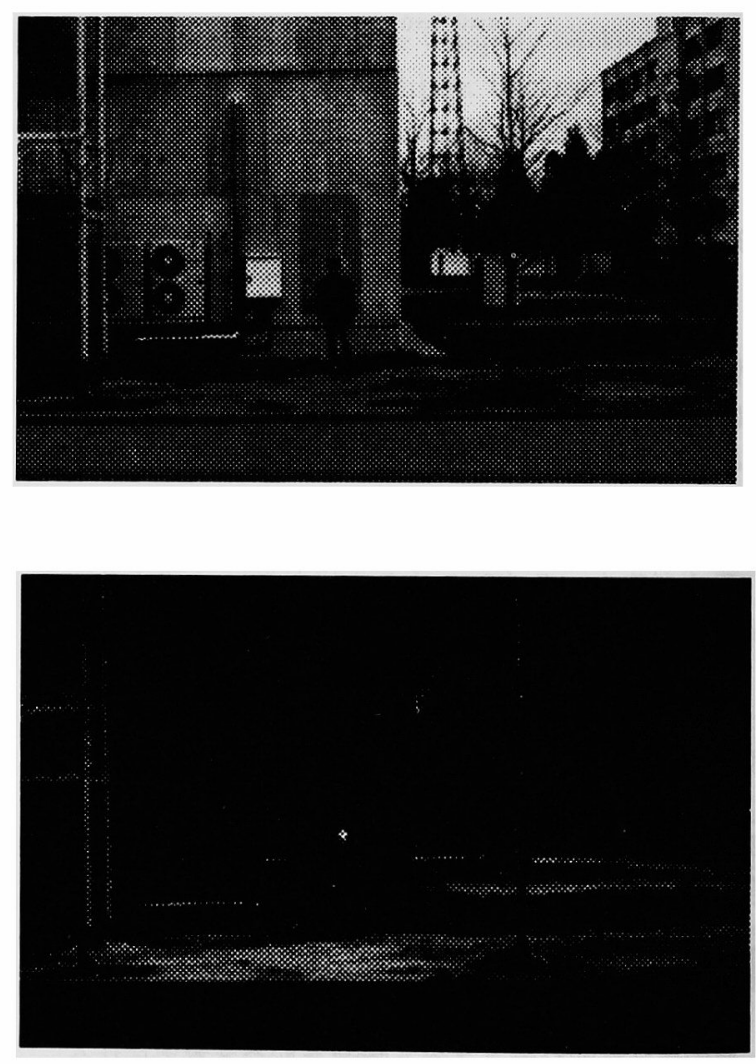

(b)

図 1: カラー画像と I 成分画像

(原画像はカラーであるが、印刷の都合で白黒で表示) Color image and I-component image (The original is a color image, but printed in monochrome) 


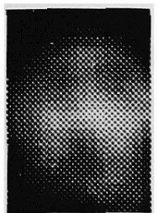

$$
B_{I}=\left(\begin{array}{lll}
0.00 & 1.01 & 2.71 \\
1.44 & 2.05 & 3.55 \\
4.53 & 4.85 & 5.98
\end{array}\right)
$$

図 2: 顔画像の例とその $B_{I}$

An example of facial image and its $B_{I}$

$$
\begin{aligned}
& B_{C}=\left(\begin{array}{lll}
1.00 & 0.83 & 0.66 \\
0.82 & 0.69 & 0.54 \\
0.62 & 0.52 & 0.41
\end{array}\right) \\
& B_{D}=\left(\begin{array}{lll}
1.00 & 0.58 & 0.39 \\
0.53 & 0.46 & 0.37 \\
0.32 & 0.29 & 0.28
\end{array}\right)
\end{aligned}
$$

図 3: 顔画像から計算した $B_{C}$ と $B_{D}$ の例

$B_{C}$ と $B_{D}$ calculated from the face in Fig.2

$B_{I}$ については (7) と同じく、次式が成立する：

$$
B_{I}\left(j_{1}\right)<(1+w) B_{I}\left(j_{2}\right) \quad\left(j_{1}<j_{2}\right)
$$

ここで、 $w$ は正定数、 $j_{i}$ は $B_{I}$ の要素の番号である。

図 2 具体例で、 $B_{I}(2,1)$ と $B_{I}(1,2)$ を例にとれは。 $j_{1}=7 、 j_{2}=8$ であり、 $B_{I}(7)=3.55$ は $B_{I}(8)=$ 4.85 より小さく、式 $(10)$ が確かに満たされる。

白黒画像では、式 $(8)$ のように、 $B_{D}$ に顔の特徴が現 れていた。しかし、I成分画像について、多数の画像を 視察した結果、 $B_{D}$ より $B_{C}$ に顔の特徽が現れること が分かった。図 2 の 成分顔画像を使って $B_{C}$ と $B_{D}$ を 計算した結果を図 3 に示す。

I成分画像において、顅の特徽として、 $B_{D}$ と $B_{C}$ の いずれが優れているかを理論的に考察するのは困難で ある。そのため、本研究では実験的に優劣を判定する こととした。多数のI 成分顔画像について、 $B_{D}(j)$ 及 び $B_{C}(j)$ の変動係数 (= 標準偏差 / 平均) を求めた。具 体例をあげれば、 $B_{D}(2)$ の変動係数は $0.09 、 B_{C}(2)$ の それは 0.06 であった。全般的に、 $B_{C}(j)$ の変動係数は $B_{D}(j)$ よりも小さく、顔の特徽として優れていると判 定した。

この結果、本論文では、 $B_{I}$ と $B_{C}$ を顔画像の特徽と して採用した。

さらに、図3で分かるように、 $B_{C}$ の要素は要素番号 が増加すると減少の傾向を示す。この理由は I 成分顔画 像の浱焱変化が局所的には一様であるが、全体的には非 一様であることに基くものと考えられる。さらに、I 成 分画像の中の顔はだいたい同じ様子をしているので、䟴 度の空間的分布の分散はほぼ同一の範囲にあると考え られる。従って、 $B_{C}(j)$ はある範囲内に存在している
と期待される。 $B_{C}(1)$ は 1 であるから、 $j>1$ なら ば、1より小さい正パラメータ $c_{1}(j), c_{2}(j)$ が存在し、 式(11) が成立すると考えられる。

$$
c_{1}(j)<B_{C}(j)<c_{2}(j) \quad(1<j \leq 9)
$$

ここで、 $c_{1}(j)$ と $c_{2}(j)$ は正パラメータである。

式 (11) も、顔画像と非顔画像を判別する基淮として 使用できる。

パラメータ $w 、 c_{1} 、 c_{2}$ は前論文 ${ }^{(10)}$ に述べたのと同 様な学習法により決定される。

\section{3 画像の雑音除去}

カラー信号から I 成分画像に変換する際、ある程度の ごま塩状の雑音が発生するので、雑音除去が必要とな る。本論文ではこのごま塩状の雑音に効果的な平滑化、 すなわち、ある条件を満足する点だけを対象に平滑化す る方法を適用した。この方法は $3 \times 3$ の空をマスクと して、対象とする画像の各画素に順次にこのマスクを当 て、画素の值の線形結合を用いてフィルタを施す手法で ある。このフィルタは次のように表される。

$$
\begin{aligned}
& g(i, j)=\left\{\begin{array}{rc}
0 ; & \sum_{(k, l) \in R} a(k, l)>6 \\
f(i, j) ; & \text { 上記以外 }
\end{array}\right. \\
& a(k, l)= \begin{cases}1 ; & f(k, l)=0 \\
0 ; & \text { 上記以外 }\end{cases}
\end{aligned}
$$

ここで、 $f(i, j)$ と $g(i, j)$ はそれぞれ平滑化前後のI 成 分画像画素, $R$ は $3 \times 3$ のマスク領域である。

\section{4 顔抽出手法}

本節では、前節の顔テクスチャモデルを用い、カラー 情報を利用した顔部分の抽出法を提案する。

ここでは主に複雑自然背景画像からの低画質顔画像の 抽出について検討する。対象とする低画質とはコンピュ 一タにより顔画像を識別できる限界の粗い分解能を考え る。予備実験の結果 (9) では、識別できる顔の最低解像 度は $16 \times 20$ 画素であった。そこで、空の最小サイズを $16 \times 20$ にとった。

顔の大きさが異なれば、空の大きさの調整が必要であ る。本論文では、顔の大きさの変動範囲はあまり大きく なく、1〜2 倍の範囲とした。このような制限をおいて も、意味のある用途は広いと考えられる。

顔の大きさの変化が大きくないとき、 $B_{I}$ の位置に対 する変化の模様を用いて、空サイズが顔の大きさに適 合しているかどうか判定できる。実験によれば、空を 顔の近傍で水平方向に移動するにつれて、 $\left(B_{I}(0, n)-\right.$ $\left.B_{I}(m, 0)\right)$ は放物線のように変化する。空の大きさが 顔とほぼ等しい場合、空が顔とほほ重なったときに、 $\left(B_{I}(0, n)-B_{I}(m, 0)\right)$ は最大値をとる。

密の大きさが顔と一致していないとき、 $\left(B_{I}(0, n)\right.$ $\left.B_{I}(m, 0)\right)$ の值は上の特徴を表さない。その特性を利用 
して、顔の大きさに応じて、窘の大きさを修正し、顔の 正しい位置を検出する可能性があるが、詳細は紙面の都 合で省略し、文献 ${ }^{(10)}$ に蛽る。

I 成分画像からの顔の検出では、白黒画像の場合と異 り、空の中で常に顔テクスチャモデルを計算する必要は ない。まず、空によりI成分画像の全体を走查して、空 内の濃淡平均値を計算する。この平均值がしきい值 (実 験では 4 とした) よりも小さけれぼ、空内の画素の大半 は黒い画素と判定できる。このとき、空領域は顔でない と判定し、この領域をスキップする。

空内の漶淡平均值がしきい值より大きい場合には、顔 が存在する可能性がある。そのときのみ、 $B_{I}$ と $B_{C}$ を 計算し、その要素が不等式 $(10)$ と (11) を満たす場合、 この空の位置を顔領域の位置の候補とする。この過程を 全画面の走查が終わるまで続ける。

空の水平および垂直方向の移動ビッチはそれぞれ空の 幅と高さの $1 / 3$ とした。したがって、ある顔領域は複数 の空で重䙡して抽出されるかもしれない。重複した抽出 領域から一意的に顔部分領域を定めるため、前論文 ${ }^{(10)}$ に用いた手法で処理する。

\section{4. 実験結果}

4.1 顔テクスチャ特徽モデルの考察
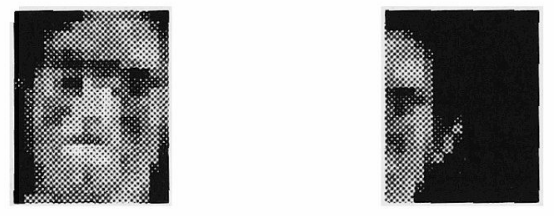

full facial $1 / 3$ facial
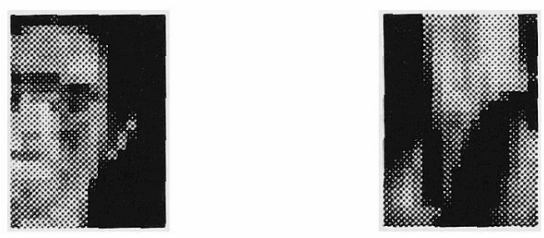

$2 / 3$ facial

non_facial

図 4: 表 1 の実験で用いた画像の例

Variety of test samples

used in the experiments of table 1

不等式 $(10)$ と (11) におけるパラメータ $w, c_{1}(j), c_{2}(j)$ を求めるために、20 枚の顔画像のサンプルを用いて、 実験を行った。これらの実験用のサンプルは 10 人の顔 に対する顔画像である。顔の解像度は $16 \times 20$ 画素程 度であるから、 $M=2$ と $N=2$ とした。実験によっ て、前論文 ${ }^{(10)}$ による学習アルゴリズムは良好な収束性 を示した。得られたパラメータは $w=0.3 、 c_{1}(2)=$ $0.75 、 c_{2}(2)=0.85$ であった。

顔テクスチャ特徵モデルの有効性を確認するため、人
表 1: 小さい領域に対する顔判定の実験結果

Experimental results for face identification in small regions

\begin{tabular}{|c|c|c|}
\hline \multicolumn{2}{|c|}{ test samples } & rate determined as faces \\
\hline case & number & \\
\hline full facial img. & 20 & $100 \%$ \\
2/3 facial img. & 10 & $80 \%$ \\
1/2 facial img. & 10 & $40 \%$ \\
1/3 facial img. & 10 & $6 \%$ \\
nonfacial img. & 50 & $4 \%$ \\
\hline
\end{tabular}

工的に作成した部分顔画像で顔の識別実験を行なった。 サンプルは全顔、部分顔、顔なしの 3 種類の画像を I 成 分画像に变換したものである。部分顔は、顔部分の含有 率によって $2 / 3,1 / 2,1 / 3$ の 3 種類に分れる。このう ち、 4 種類の例を図 4 に示す。

表 1は、サンプル種類別の識別実験の結果を示してい る。表 1 には同時にサンプル数も示す。

表 1に見られるように全顔のサンプルでは、見落とし 率は $0 \%$ であった。一方、非顔画像を顔として識別した 割合 (虚報率) は $4 \%$ であった。また、部分顔を含むサ ンプルに対して、その識別率は画像中に含まれる顔の含 有率の単調增加関数となった。

以上の実験結果から、顔の判断基準として、不等式 (10) と (11) で構成した顔のテクスチャモテルが妥当で あることが確認された。

\section{2 顔抽出実験と結果の解析}

以上に提案した手法の有効性を確認するために、合わ せて 20 個の顔を含む複雑自然背景画像 10 枚を使い、 顔抽出の実験を行った。この 10 枚の画像はパラメータ の学習に用いた画像と別であり、未知サンプルセットで ある。

これらの実験用画像は日中の写真である。建物と榯な どの屋外環境及び机と本棚などの室内環境のような情景 を背景とする。また、これらの画像サンプルには、正面 を向いた人物が画像中のいろいろな位置にあって、顔の 大きさが $16 \times 20$ から $20 \times 26$ まで変化している。

実験の結果、10 枚の画像中の 18 個の直立顔画像が 正確に抽出された。しかし、傾斜顔 2 個のうち、見落と しが 1 個ある。さらに、1枚の画像では、虚報が 1 個生 じた。

図 5にこの実験で用いた原画像と抽出結果の例を示 す。図 5で、白い枠は抽出した顔の領域を示す。図5(a) は、図1(b)に示したカラー室外自然情景のなかに、一 つの顔がある場合の抽出結果で、顔の部分が正確に抽 出されている。図 5(b) の原画像では、カラー室内自然 風景のなかに、3 個の顔が含まれる。(c)に示すように このうち 2 個の直立顔の部分が正確に抽出された。しか し、傾斜顔を見落とした。さらに、1 個の虚報が抽出さ れた。細かく言うと、虚報部分は見落とした顔の一部を 


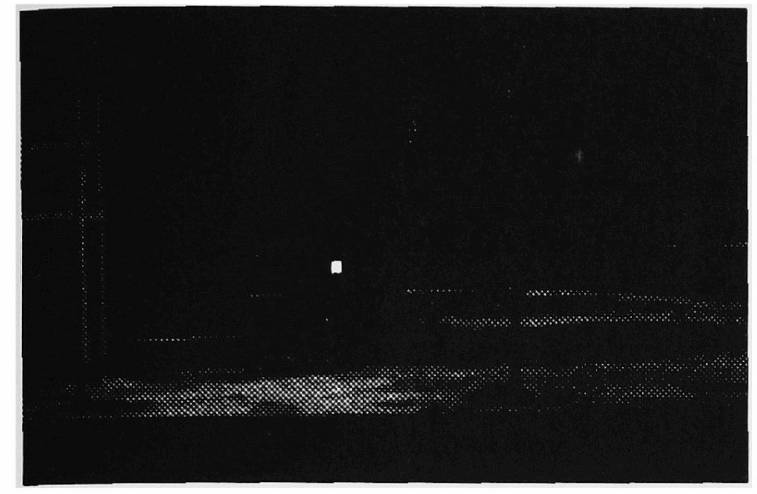

(a resolution of image is $1142 \times 738$ pixels)

(a)

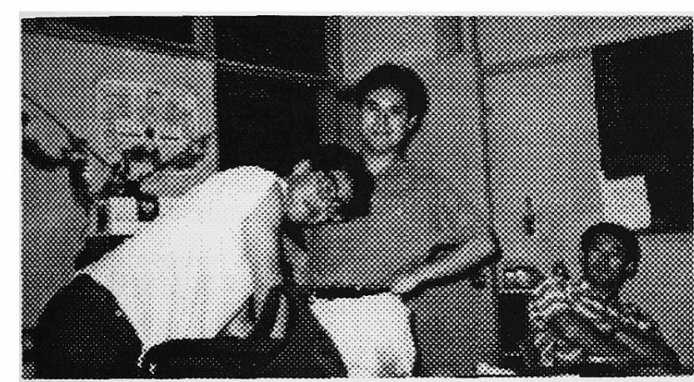

a original image

(a resolution is $213 \times 113$ pixels)

(b)

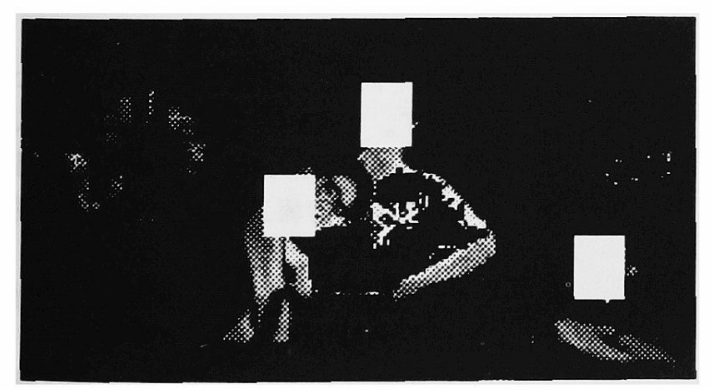

a detection result

(c)

\section{図 5: 顔画像の抽出領域}

Detected facial regions

(a) corresponds to the original image in Fig.1 (b)
含んでいるので完全な失敗とは言えないが、本論文では 見落とし 1 個、虚報 1 個と数えた。

傾斜顔が見落とされた理由は、顔の傾きが大き過ぎ て、本法の適用範囲から出たためと考えられる。

虚報は、少いことが望ましい。しかし、検出部におい ては、見落された顔画像は絶対に認識できないため、見 落しが少いことが重要である。一方、虚報があったとし ても、認識部で reject できる可能性があるので、多少の 虚報は許されると考えて良い。その意味で、本実験結果 は渵足し得る。

カラー画像は白黒画像より顔抽出に対して有効であ ることを検証するために、顔抽出実験に使ったカラー画 像を白黒画像に変換し、前の顔抽出手法により、これら の白黒画像における顔抽出を実行した。変換方法は R, $\mathrm{G}, \mathrm{B}$ の単純平均である。図 6は図 $5(a)$ に使ったカラー 画像から変換した白黒画像とこの白黒画像における顔抽 出結果を示した。図6で分かるように、真の顔は正しく 抽出されたが、虚報が 14 個生じた。

本手法の副次的な勃果として、処理速度も向上され る。I成分画像に対して、空内の平均浱度がある值より 小さいとき、すぐスキッブするので、SGLD 行列を計 算する負荷は減り、処理速度が速くなる。図6に示した 白黒画像に対する前手法の処理時間はカラー画像に対す る本手法の時間の 5.5 倍になった。

この結果により、画像のカラー情報を正しく利用すれ は、複雑自然情景からの顔の抽出の精度や速度の向上に 有効であることが分かった。

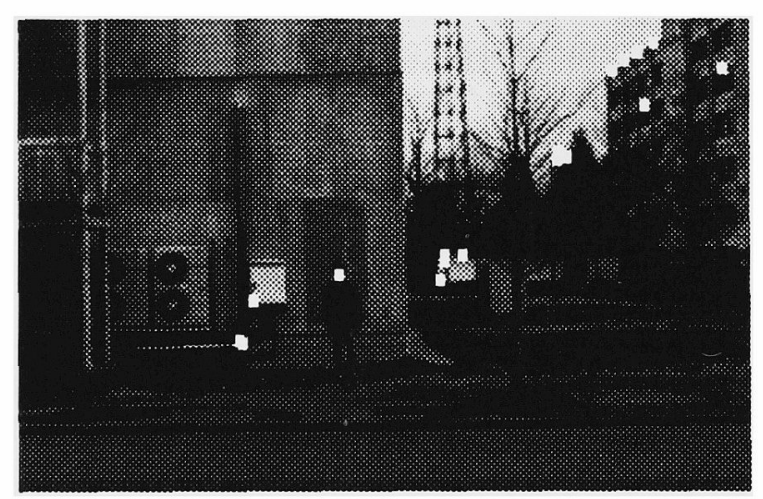

図 6: 前手法による白黒画像からの顔抽出領域 Detected facial regions in monochrome image by the previous method

\section{5. むすび}

共起行列に基づく顔のテクスチャモデルを用いたカ ラー複雑自然背景画像からの低画質顔画像の抽出法を 提案した。この方法では、カラー画像中の肌色の部分 を强調するI成分画像を構成し、このI成分画像から SGLD 行列を計算し、その要素に対する二つの特徽パ ラメータ不等式を得た。これらの不等式を使って、顔の 
テクスチャモデルを構成した。顔のテクスチャモデルに 含まれるパラメータは訓練サンプルに対して実験で定め た。

本手法では、自然背景画像からの低画質顔の検出を目 的としたため、 $16 \times 20$ 画素の大きさの空で画像を走査 し、上記不等式を満たす部分を顔候補として検出した。 本実験で使用したサンブルでは顔の大きさは $16 \times 20$ 画 素〜20×26 画素であった。

本手法を 20 個の末学習正面顔画像を含む 10 枚の自 然情景画像からの顔検出に適用した。顔部分の大きさは $16 \times 20$ 画素から $20 \times 26$ 程度である。実験の結果、 18 個の直立顔画像は全て正しく検出されたが、1 個の虚報 と 1 個傾いた顔の見落としを生じた。ただし、この見落 としは傾いた雇画像であり、虚報 1 個はこの見落された 顔の一部を含んでいる。

このように、カラー情報を利用したことにより、直立 顔については見落としがなく、虚報も少なくなることが 分かった。さらに、非顔部分を早い段階で排除できたた め、白黒画像の場合に比へて、顔の検出速度が 5.5 倍向 上した。

今後の課題として、顔が回転したり傾いたりした場 合に本法を拡張することが必要である。また、本手法は $16 \times 20$ 画素程度の極めて粗い画像を対象としている が、逆に高分解能の画像には適用できないのではないか という疑問も残る。ただし、高分解能画像の場合には、 低分解能に変換することは容易であり、本手法は適用可 能であるが、大きさの変換比をいかに選ぶかは今後の課 題である。本手法は、東アジア系人種には有効であり、 当面日本国内で使用するには有効であろうが、その他の 人種に対する検討は今後の課題である。

(平成 6 年 12 月 27 日受付、同 7 年 8 月 4 日再受付)

\section{文 献}

(1) L.D.Harmon et al. "Automatic Recognition of Human Face Profiles", Computer Graphics and Image Precessing 6, pp. 135-156 (1977).

(2) T.Kurita, et al. "A Face Recognition Method Using Higher Order Local Autocorrelation and Multivariate Analysis", The Proceedings of 11th International Conference on Pattern Recognition, pp.213-216, (1992).

(3) S. Akamatsu, et al. "An Accurate Robust Face Identification Scheme", The Proceedings of 11th International Conference on Pattern Recognition, pp.217-220, (1992).

(4) 小杉: "個人識別のための多重ピラミッドを用い たシーン中の顔の探索、位置決め、信学論 D-II、 Vol. J77-D-II、No.4、pp.672-681(1994)

(5) G. Yang, et al. "Human face detection in a complex background", Pattern Recognition, Vol. 27, No. 1, pp. 53-63 (1994).

(6) V. Govindaraju et al. "A Computational Model for Face Location", Proceedings of ICCV'90, pp.718-721(1990).

(7) M.Turk et al. "Face Recognition Using Eigenface", Proceedings of CVPR, pp.586-591, (1991).

(8) R. M. Haralick, "Textural Features for Image Classification" , IEEE Trans. on SMC, Vol. SMC. 3, No.6, pp. 610-621 (1973)

(9) Y. Dai, et al. "A Study of Face Recognition with Low Quality Images", The Proceedings of ICARCV'94, pp.1442-1446(1994), Singapore.

(10) Y. Dai, et al. "Extraction of Facial Images from a Complex Background Using SGLD Matrices", The Proceedings of 12th International Conference on Pattern Recognition, I, pp.137141(1994).

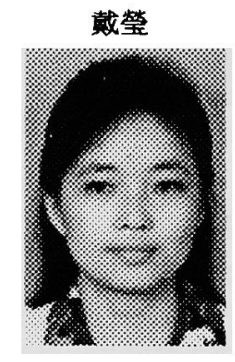

中野康明

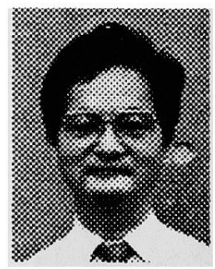

(学生員) 1988 年西安交通大学修 士課程了。1988-1990 年西安交通大 学助手、1991-1992 年華南理工大学 講師。1993 年 4 月信州大学大学院 工学系研究科博士後期課程入学、現 在に至る。画像処理、パターン認識、 特に顔画像諮識、ニューラルネット ワークなどに興味を持っている。

（正員） 1961 年東京大学工学部卒。 1963 年同大学院数物系研究科修士 課程了。1963 年 (株) 日立製作所入 社、中央研究所勤務。1989 年信州 大学工学部情報工学科教授。日立製 作所在職時には、音声合成・認識、 ソナー信号処理、文字認識、文書理 解などの研究開発に従事。現在は、 パターン認識、特に手書きならびに印刷文字認識、顔 画像認識、および意味ネットワークなど人工知能応用、 ニューラルネットワークなどの研究に興味を持ってい る。IEEE Senior Member, 電子情報通信学会、情報 処理学会各正員。工学博士。 